\title{
Analysis on the Basic Theory of the Executive Guarantee
}

\author{
BaiMei, WangYuTao \\ Institute of Political Science and Law \\ YuLin University \\ Yulin China \\ Lucybm@163.com
}

\author{
WangYuTao \\ Law Institute \\ XinJiang University \\ XinJiang, China \\ Taotao@163.com
}

\begin{abstract}
Executive guarantee system as an important civil enforcement regime, to guarantee its use to compensate for the lack of credit, with the protection of the claims of creditors, equity the debtor and stakeholder interests, maintain the function of the implementation of the order of stability. This paper analyzes the general theory of the executive guarantee, to how equitable between the parties, the relationship between the executive authorities and the parties and to seek the "organic" meeting point, lay the foundation for the system fair and efficient operation.
\end{abstract}

Key Words--Executive guarantee; the concept; legal relationship; nature; functions

\section{TO CLARIFY THE CONCEPT OF CIVIL EXECUTIVE GUARANTEE}

In essence, it belongs to a general guarantee system, is embodied in the process of debt guarantees in civil execution, the basic principles are the same. in fact it is a legal approach taken by the parties in the executive relation to pay the debt or with a third party agreed to ensure that one party should bear the obligation

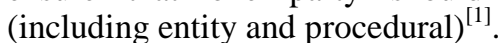

The author thinks: first, carry out guarantee start the subject is not only confined to the debtor, creditors and interested parties can also be the subject of a program start. Second, execution guarantee to execute a program is not just limited to the influence of reprieve, it could led to the suspension of execution of reprieve, and continue. Again, with "the debtor (the person subjected to execution) do have temporary difficulties, lack of solvency"to guarantee execution of the applicable conditions, will be limited to perform the guarantee applies. Finally, the execution guarantee way of guarantee, as long as it can play on creditor's rights guarantee function, is not limited to insurance, guarantee way may also apply. Thus, according to the author thinks that execution guarantee refers to the civil executive program, perform the parties or interested people to realize its program or entity on the interests of the guarantee, to stop or continue to execute a program, civil enforcement authorities decided to temporarily stop or continue to implement the system of procedure.

\footnotetext{
${ }^{[1]}$ Chen Si, "the improvement of the system: reflections on civil litigation guarantee system--in the way from the practice explore ",J, "social science of Guang Dong "in June 2002.
}

\section{DECONSTRUCT EXECUTIVE GUARANTEE LAW RELATIONS}

\section{A. Perform Double Guarantee Legal Relationship} Structure

The author thinks that execution guarantee still has a compound legal relationship, should be made up of double structure.

One is for the guarantee of legal relationship in private law. Executed between the parties, as between the parties and the guarantor, or between stakeholders and the guarantor on the basis of guarantee established principles and rules, it can be said for the basic relationship. Second law for the legal relationship of civil execution, to carry out the parties or interested party according to the basic relationship between the establishment of, apply to the enforcement authorities deterrent or resume execution process, constitute, to recognition and enforcement agencies, it can be said for the upper. At this point, marked the execution guarantee the establishment of the legal relationship. On this basis, it locates in the contractual behavior based civil executive legal relationship is more suitable.

To note two issues. First, execution guarantee legal relationship of double structure is not fragmented, but both are relatively independent and interconnected unity in execution guarantee legal relationship. Independence displays in: the formation of the basic relations to the principle of party autonomy is a process of parties exercise their right of disposition, the executing organ shall also should not interfere in. Upper relationship established for enforcement agencies the exercise of executive power, has a unilateral will, not by the will of the parties for the transfer. The mutual contact is shown as: on the premise of the establishment of the upper base relations, the establishment of the relationship between the upper based relations new legal meaning. By ordinary civil and commercial guarantee guarantee relationship at this time as by executive power supervision and guarantee. Effect on the generated executable program, namely the property for security or security for debt secured mandatory, without action is executed directly. Second, different types of execution guarantee there are differences in the proportion of two layers of legal relationship as well. Desirable execution guarantee focuses on basic relationship, performance guarantee by unfavorable is above the upper relations.

\section{B. Study on Enforcement Agencies}

The author thinks that, the execution authority as a 
leader of the enforcement procedure, in its execution guarantee the status of legal relationship, relationship to the entire executive construction of guarantee system of localization.

At present, the enforcement agencies mainly exist the following several kinds of positioning methods: first, the right of enforcement agencies as a security man. Second, the executing organ is similar to the escrow office. ${ }^{[2]}$ third, enforcement agencies is only centered review, negative discretion. Fourth, the executing organ shall the legal supervisor for the neutral. The executing organ shall guarantee in the implementation of the legal status is similar to the examination and supervision authorities. ${ }^{[3]}$

Enforcement agencies of the status and role is not appropriate to strengthen, and the principal position of creditors cannot reflect. Consequences follow, due to the weakening of the creditors' responsibility enforcement agencies face may be due to the improper establish execution guarantee, and the interests of the parties liable for the infringement. Take the second and third view on understanding have in common, that enforcement authorities should be guarantee the implementation of "detached" status, only the second view "detachment" more thoroughly. Compared with the first kind of view will perform organ with creditors divided these two views, thus effectively avoid the enforcement authorities to take risks, But if extreme this view is that the legal status of enforcement authorities in the implementation guarantee is only similar to the escrow office, execution guarantee similar to civil and commercial guarantee, against civil execution protect private rights by public power to achieve purpose and ignored the executive powers of enforcement of property.

As a result, the author agrees with the fourth point of view, will be located neutral law enforcement agencies of the supervisors. Based on the basic relationship, perform security right of guarantee shall be for the security relationship between the parties. Enforcement agencies in the implementation guarantee legal relationship roles when stay in the upper level, the exercise of review and supervision of public power. According to guarantee basic principle, guarantee right has the property, its attached to the main creditor's rights, it also forms the foundation of the main creditor guarantee rights and interests enjoyed. Enforcement agencies are not the principal claim 4 , its as collateral rights are human right of the principal claim and guarantee division, contrary to guarantee basic principle. guarantee. So-called right can be understood as acknowledged by law and safeguard the interests of whatever the rights of specific object, rise to abstract concepts, for right subject, he is always an interest or must contain some kind of interest. ${ }^{[4]}$ execution guarantee system to maximum extent, guarantee the realization of creditors, creditors share interests, guarantee security right person is the creditor. Enforcement agencies in the executive guarantee behavior, shall be construed to exercise their functions

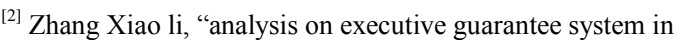
China”,(9th guidance and reference on the enforcement ,p. 113. )

${ }^{[3]}$ Yang jun, "legal status of the people's court in executive guarantee", (13th guidance and reference on the enforcement ,p. 111. )

${ }^{[4]}$ Zhang Wen xian, "jurisprudence", higher education press, 2003, p. 108 .
}

and powers. enforcement authorities also are regarded as external condition ${ }^{[5]}$ Will perform organ located in monitors, but will the exercise of executive power and the responsibility of the corresponding protection of the rights, the parties to creditors' rights and interests enjoyed and corresponding risk, streamline execution guarantee legal relationship main body relations, achieve rationalization of risk-taking. supervision, check and supervise, check and supervise the neutral, and negative its still contain positive as ingredients, this also is the embodiment of the executive power has the attributes of executive power. The respect of the enforcement of rights on the parties, as an execution guarantee system is one of the theoretical basis, but the parties autonomy also often appear in form of equality cover a substantial inequality, the executing organ is responsible for the prompt execution guarantee responsibility according to law, make the execution guarantee under the vision of the executive power. In the execution guarantee, the executing organ to guarantee shall investigate endowed with supervision.

Executive guarantee executive authority status in legal relationship orientation problem manifests the execution guarantees the nature, the essence of which lies in the equity executive power with other subject right. Execution guarantee is the nature of public power under the supervision of private rights, enforcement agencies position shall be reflected on the parties right to respect, at the same time reflect execution guarantee procedural meaning and the characteristics of the supervision to executive power. Thus, in execution guarantee, will be located the law enforcement agencies of the supervisors should be appropriate.

\section{ANALYSIS ON NATURE AND FUNCTION OF THE EXECUTIVE GUARANTEES}

\section{A. The nature of the executive guarantee}

Execution guarantee system as a guarantee system concrete application in the field of civil execution, is the guarantee system can be integrated with the civil enforcement procedure. It is executing the tone of this guarantee to the nature of the present compound and complexity.

\section{1) In the perspective of demarcation between rights and power}

Perform guarantee is the unity of dominance and executive power participation rights by the parties.

Perform a dominant rights by the parties. The essence of the enforcement procedure is to realize the private rights. Perform the parties and interested persons as executive relationship of participants, interests realization and guarantee of the main body, what is the most know their interests, and to choose the best way to realize their own rights and interests as the starting point. First of all, the application is to start running the parties and interested persons guarantee condition. This can be called the execution guarantee legal relationship main body in the procedural right. Secondly, from the guarantee system of execution of one of the main theoretical basis guarantee principle. In the absence of any mandatory provisions of the law, between the parties about the

\footnotetext{
${ }^{[5]}$ Suli, "Posner and other: after translation ", law press, 2004,p.83.
} 
guarantee of party autonomy has the force of law, guarantee relationship the parties shall have the real intention, etc. Disposition is the foundation of this agreement, whether to suspend to perform the creditors to guarantee the implementation of punishment, or the execution reconciliation guarantee the original execution according to the entity right to dispose of, are evident. For guarantee unfavorable, although no execute acceptability party established condition, but we can't deny the applicant and the guarantor agreement exists.

Generally speaking, the execution organ plays the role of supervisors, the execution guarantee the exercise of executive power, then change into execution or interested parties exercise their right to guarantee the implementation of supervision.

\section{2) In the perspective of behavior structure}

Specific to implement the guarantee behavior, perform the parties or interested party start executing organ authority behavior intention through the implementation of the contract behavior, in order to achieve the civil enforcement procedure, the content of execution, etc. And the influence of the change. Is based on hope to enforcement authorities to adopt a special behaviors and creating legal relations. If the doctrine of public law is superior to the civil law, the existence of the execution behavior improves the legal level and effect of the original contract behavior. If the doctrine of public law and private law is parallel, it is the combination of contract execution behavior and behavior, and restraining each other.

The author believed that will enforce the guarantee nature of the interpretation of the exercise of public power under the supervision of private rights should be in order.

\section{B. perform the function of guarantee}

Function is the thing, thing or method of favorable effect. "A kind of social facts should always to it with a social purpose to search for the relationship." ${ }^{,[6]}$ the author thinks that the guarantee system of execution of function to perform and guarantee their function as the basis, but not the simple sum of the two functions and beyond, but the two functions of organic fusion to produce a unique and irreplaceable role. The author tries to perform the function of guarantee legal relationship of the parties as the starting point, and extended to the executable program go smoothly, and to fit with the social value in three aspects.

\section{1) Guarantee function, protection of creditors}

To be specific, the guarantee of the suspended function is to suspend execution creditors may be the damage compensation. There "probably" damage, including execution according to the creditor and the debtor fails to fulfill its part and creditors due to suspend the performance of the amount of damage. Guarantee of the execution reconciliation function is to creditors after execution reconciliation agreement, the debtor fails to carry out part according to the settlement of the damage compensation. Execution relief guarantee function is to stop or continue to perform to may be the damage

${ }^{[6]}$ E.durkheim, "the rules of sociological method"the commercial press, 1995, p. 125 compensation. Here to be sure, the risk of "may" damage burden, can be transferred or scattered, namely guarantee responsibility for ways and scope available by its execution guarantee agreed by the parties. But guarantee the responsibility scope and intensity can be less than but not more than more than "may be" damage.

2) The rights and interests of equity, combining rights against the debtor

Implement the system of guarantee is adhering to the trend of the legislation. We can say that it is within the scope of the protection to creditors, endows the debtor's choice, time limit for the payment of the debt choice and performance of the way. of course, this is likely to compromise with creditors for conditions, but in good balance, to protect the basic rights and interests of the debtor in a certain extent, sacrifice the rights and interests of creditors is conform to the modern idea of rule of law. Sacrifice, of course, should be within the limits of necessity, this limit is the creditor's rights realize maximizing creditors. Thus, guarantee the implementation of the premise, should be duly fulfil will give the obligor to pay off the debts cause significant loss or increase the difficulty of, is not the subjective or no ability to perform. In guarantee under the premise of according to be implemented, both the legitimate rights and interests of the debtor, make it not be in a difficult insolvency was enforced, to lose the chance of survival and development.

3) Order maintenance - to execute a program

For the parties, their attention is often the realization of private right. From the point of view of the public and private rights to realize the results on the effectiveness of experience, can strengthen its internal confirmation on the authority of law, thus achieve the effect of maintaining social order. The author thinks that the guarantee system of execution in the executable program of two aspects of fairness and effectiveness results of appeal, can play an important role.

Executive guarantee has remedial function to the executable program integrity. Whether it is in the suspended temporarily guarantee, or in the execution reconciliation guarantee the implementation of relief in the guarantee, are carried out through the application of resistance or continue to achieve substantive pursuit to justice enforcement procedure, the executive procedure more smoothly. Secondly, implement the system of guarantee to the executive power to define the scope, the enforcement authorities exercising the private right "watchdog" role, in the enforcement agencies protect private rights by the parties at the same time minimize the enforcement of the rights violations. So as far as possible in order to program the impartiality of the Angle to ensure the validity of the results.

Executive guarantee system for the executor, therefore, it has to carry out difficult remedial procedure justice and resolve double efficacy. To improve the possibility of a case ZhiJie, maintain the authority of the law and maintaining social order.

\section{REFERENCES}

[1] Chen $\mathrm{Si}$, "the improvement of the system: reflections on civil litigation guarantee system--in the way from the practice explore ",J, "social science of Guang Dong "in June 2002. 
[2] Zhang Xiao li, "analysis on executive guarantee system in China",(9th guidance and reference on the enforcement, p. 113. )

[3] Yang jun,"legal status of the people's court in executive guarantee", (13th guidance and reference on the enforcement ,p. 111.)

[4] Zhang Wen xian, “jurisprudence”, higher education press, 2003, p.108.
[5] Suli, "Posner and other: after translation ", law press, 2004,p.83.

[6] E.durkheim, "the rules of sociological method"the commercial press, 1995, p.125. 